\title{
Parasites in the mangrove oyster Crassostrea rhizophorae cultivated in the estuary of the Graciosa River in Taperoá, Bahia
}

\author{
Parasitos na ostra-do-mangue Crassostrea rhizophorae cultivada no estuário \\ do rio Graciosa em Taperoá, Bahia \\ Aliane Watanabe Cova ${ }^{1 *}$; Moacyr Serafim Júnior ${ }^{1}$; Guisla Boehs ${ }^{2}$; Jackson Moreira de Souza \\ ${ }^{1}$ Postgraduate Program in Animal Sciences, Federal University of Recôncavo da Bahia - UFRB, Cruz das Almas, BA, Brazil \\ ${ }^{2}$ Department of Biological Sciences, State University of Santa Cruz - UESC, Ilhéus, BA, Brazil
}

Received September 11, 2014

Accepted December 1, 2014

\begin{abstract}
In this work, parasites associated with the mangrove oyster Crassostrea rhizophorae were studied at a cultivation unit in the estuary of the Graciosa River in Taperoá, Bahia. On a monthly basis, between April 2011 and March 2012, 20 oysters were collected, measured and fixed in $10 \%$ formaldehyde. In order to identify the parasites, routine histological techniques were used. The specimens were embedded in paraffin and sections, $7 \mu \mathrm{m}$ thick, were cut. These were then stained with Harris hematoxylin and eosin and were examined using an optical microscope. The parameters analyzed to investigate water quality showed that the temperature ranged from $23.9^{\circ} \mathrm{C}$ to $29.3{ }^{\circ} \mathrm{C}$, water salinity from 0.4 to 24.2 Practical Salinity Units PSU and recorded rainfall from $80 \mathrm{~mm}$ to $406.4 \mathrm{~mm} / \mathrm{month}$. During the parasitological analyses, infestation of the polychaete Neanthes succinea was observed in $41 \%$ of the oysters. Through histological techniques, the following parasites were identified: colonies of Rickettsia-like organisms (RLOs); the protozoa Nematopsis sp. and Ancistrocoma sp.; the turbellarian Urastoma sp.; the metacestode Tylocephalum sp. and an unidentified tapeworm. The data collected showed that there was low-intensity infection with and prevalence of parasites, except for Nematopsis sp., thus attesting that these cultivated oysters were in a healthy condition.
\end{abstract}

Keywords: Histology, protozoa, Nematopsis sp., Neanthes succinea, bivalves.

\section{Resumo}

No presente trabalho, parasitos associados à ostra-do-mangue Crassostrea rhizophorae foram estudados em uma unidade de cultivo no estuário do rio Graciosa em Taperoá, Bahia. Mensalmente, entre abril de 2011 e março de 2012, 20 ostras foram coletadas, mensuradas e fixadas em formol a 10\%. Para a identificaçáo dos parasitos, foram utilizadas técnicas histológicas de rotina, com inclusão em parafina e obtenção de cortes com $7 \mu \mathrm{m}$, corados com hematoxilina de Harris e eosina e examinados em microscopia de luz. Os parâmetros analisados para a qualidade da água mostraram que a temperatura variou de $23,9^{\circ} \mathrm{C}$ a $29,3^{\circ} \mathrm{C}$, a salinidade de 0,4 a $24,2 \mathrm{PSU}$ e a pluviometria de $80 \mathrm{~mm}$ a $406,4 \mathrm{~mm} / \mathrm{mês}$. Nas análises parasitológicas foram observadas infestaçóes do poliqueta Neanthes succinea em $41 \%$ das ostras. A partir das técnicas histológicas foram identificados os seguintes parasitos: colônias de organismos assemelhados a Rickettsiae (RLOs); os protozoários Nematopsis sp. e Ancistrocoma sp.; o turbelário Urastoma sp.; o metacestóide Tylocephalum sp. e um platelminto não identificado. Os dados obtidos mostraram baixa intensidade de infecção e prevalência de parasitos, exceto para Nematopsis sp., atestando a boa condição de saúde das ostras no cultivo.

Palavras-chave: Histologia, protozoário, Nematopsis sp., Neanthes succinea, bivalves.

\footnotetext{
*Corresponding author: Aliane Watanabe Cova, Postgraduate Program in Animal Science, Centro de Ciências Agrárias, Ambientais e Biológicas - CCAAB, Federal University of Recôncavo da Bahia - UFRB, Rua Rui Barbosa, 710, Centro, CEP 44380-000, Cruz das Almas, BA, Brazil, e-mail: alianewatanabe@hotmail.com
} 


\section{Introduction}

Bivalve mollusks are filter feeders and consequently they feed on particles that are suspended in water. Because of this characteristic, they are considered to be carriers of numerous pathogens for humans, given that they primarily bioaccumulate bacteria such as those from the genera Salmonella and Shigella, along with enteric viruses and protozoa. This mainly happens because of fecal contamination at cultivation sites (LEE et al., 2003).

According to Boehs et al. (2012), the main marine bivalve diseases on the Brazilian coast are: bacterioses, mycoses, protozoosis (caused by: Ciliophora, Apicomplexa, Perkinsozoa, Haplosporidia, Paramyxea and Microspora), metazooses (caused by: Turbellaria, Digenea, Cestoda, Polychaeta, Pinnotheridae, Copepoda), neoplasms and other tumors.

Studies looking at parasites in bivalve mollusks have provide an insight into the extent of the problems caused during bivalve mollusk production (SILVA et al., 2002; SABRY \& MAGALHÂES, 2005). In many cases, diseases due to pathogens cause repeated losses, decimating stocks and thereby stalling the bivalve production industry. The same happened with the European oyster (Ostrea edulis), which was severely affected by the protozoa Marteilia refringens and Bonamia ostrea (SILVA \& VILLALBA, 2004). These parasites spread during the 1970s and 1980s, dramatically reducing production in the main bivalve cultivation areas in Europe. There were no methods available to eradicate them, and therefore these diseases endemically persisted in most natural oyster beds and oyster farming areas, thus making any production enterprise impossible (ABOLLO et al., 2008; FAO, 2013).

In Brazil, the first recorded cases of parasitoses in edible bivalve mollusks date from 1966, in a study on a trematode parasite that was feeding on the pointed venus (Anomalocardia brasiliana) (NARCHI, 1966). To assist in developing oyster and mussel cultivation, the first research groups investigating the health of these animals were formed (COSTA, 2007). Recent studies on parasites in bivalve mollusks with potential for cultivation on the Brazilian coast have been developed with using the oysters Crassostrea rhizophorae and C. gigas, the mussels Perna perna and Mytella guyanensis and the cockle $A$. brasiliana (BOEHS et al., 2012).

In Bahia, and specifically in All Saints' Bay (Baia de Todos os Santos), Nascimento et al. (1986) found various parasites in C. rhizophorae, including the protozoa Nematopsis sp. (Apicomplexa) and Ancistrocoma sp. (Ciliophora); a trematode of the genus Bucephalus and a cestoid of the genus Tylocephalum.

The expansion of oyster cultivation in communities in Brazil's coastal regions highlights the need to develop studies relating to diseases in bivalve mollusks that are caused by parasites, since increased cultivation may trigger the spread of these organisms, through the proximity and density of specimens. Based on this assumption, the present study aimed to investigate the parasites associated with $C$. rhizophorae oysters at a cultivation unit in the Graciosa River estuary in the municipality of Taperoá, located in southern Bahia.

\section{Materials and Methods}

Taperoá is a municipality located in the southern lowland region of the state of Bahia, and it is $282 \mathrm{~km}$ south of the state capital, Salvador. The municipality has a tropical climate, (Af $=$ humid or superhumid tropical climate accordind to Köppen classification), with an annual average temperature of 19.4 to $24.6^{\circ} \mathrm{C}$; temperatures below $15^{\circ} \mathrm{C}$ have never been recorded. Rainfall is very common and occurs most frequently in April and August, with a total rainfall of around 1100 to $2000 \mathrm{~mm}$ per year (SEI, 2013).

Oysters were collected from the cultivation area located in the village of Graciosa, situated between the municipalities of Valença and Taperoá, at the UTM (Universal Transverse Mercator) geographical coordinates E 489960.575 and N 8509845.632 (Figure 1).

Twenty $C$. rhizophorae specimens were collected every month between April 2011 and March 2012. The oysters were packed

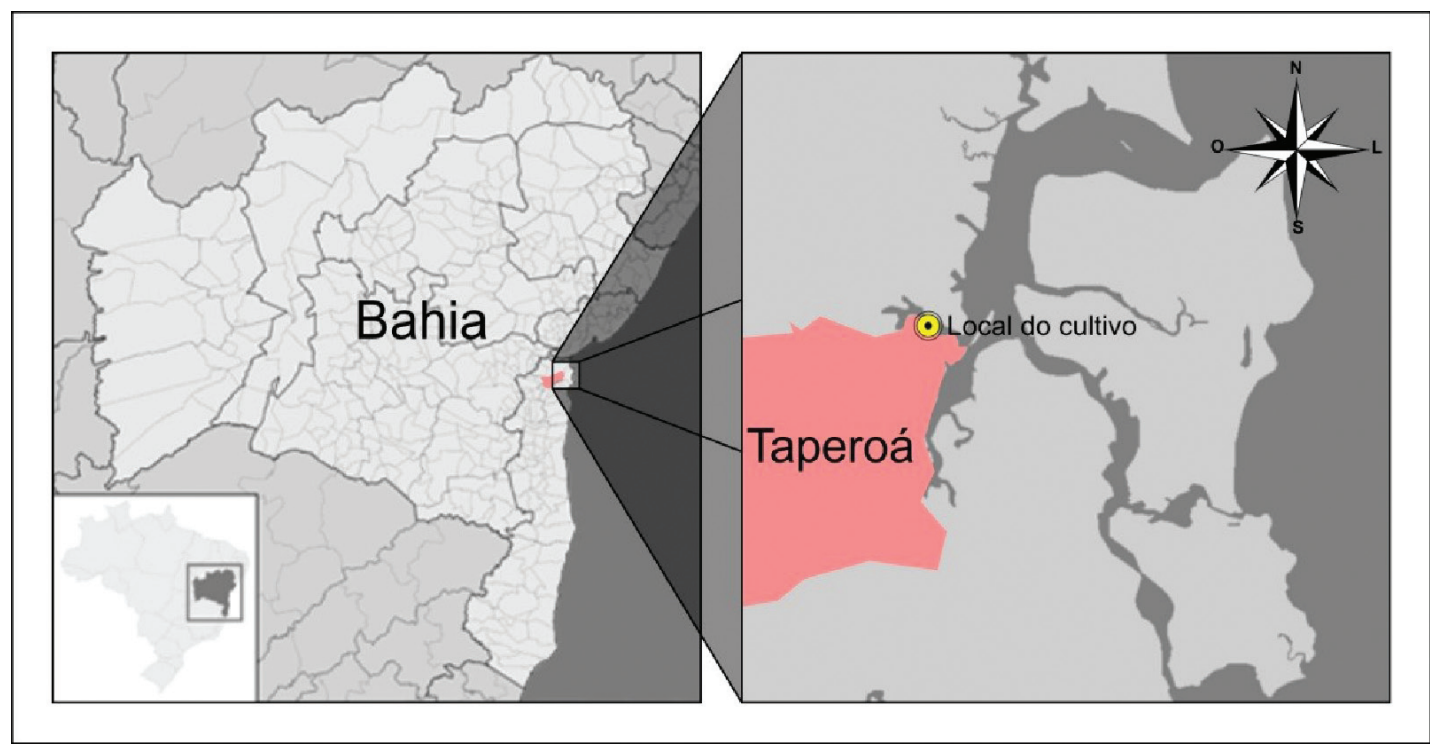

Figure 1. Study area location. 
in labeled plastic bags and were transported from the site in cool boxes with ice and water to the Invertebrate Zoology Laboratory at the Federal University of Recôncavo da Bahia, Cruz das Almas campus, in order to determine biometrics (length, width and height), wet weight and macroscopic features.

At the same time, measurements were made on the environmental descriptors of temperature and salinity (using a multi-parameter probe), at the cultivation site.

In order to determine the biometrics and wet weight, a caliper of precision $0.05 \mathrm{~mm}$ and a digital scale were used, respectively. Before opening the valves, height, width and thickness measurements were made, in accordance with Galtsoff (1964). After the oysters had been opened using a short-bladed knife, which was then inserted between the two valves in order to section the adductor muscle, the oysters were examined for macroscopic changes and evidence of parasites.

Histological sectioning was conducted partly at the Center for Fishery and Aquaculture Studies (NEPA) and partly at the Histology and Embryology Laboratory, at the Federal University of Recôncavo da Bahia. For histological analysis, soft tissues were removed, in a diagonal direction from the visceral mass, and samples were taken from the gills, digestive tract, mantle and gonads of each specimen, in accordance with recommendations of Howard et al. (2004). Subsequently, the samples were fixed in $10 \%$ formaldehyde solution, for $24-48$ hours, and were kept in $70 \%$ alcohol until histological processing.

The histological processing consisted of subjecting the soft tissues to processes of dehydration in ethanol baths, diaphanization in xylene baths, impregnation in liquid paraffin and embedding in paraffin.

Histological sections, $7 \mu \mathrm{m}$ thick, were taken with the aid of a microtome, and these were stained using the Harris hematoxylin and eosin method (H\&E). The histological slides were evaluated using optical microscopy to register the parasites, which were then identified and photomicrographed.

The prevalence of parasites was calculated in accordance with Bush et al. (1997), and was defined as the number of infected animals per sample, expressed as a percentage.

\section{Results}

The water temperature was found to range from $23.9^{\circ} \mathrm{C}$ in June 2011 to $29.3^{\circ} \mathrm{C}$ in March $2012(26.9 \pm 2.0)$; salinity from 0.4 PSU in April 2011 to 24.2 PSU in December 2011 (10.5 \pm 9.1); and rainfall from $80 \mathrm{~mm}$ (minimum) in September 2011 to $406.4 \mathrm{~mm}$ (maximum) in April 2011 (147.7 \pm 89.3).

The results obtained from biometrics showed that $C$. rhizophorae had the following average values: height $=81.4 \pm 10.6 \mathrm{~mm}$; width $=51.2 \pm 8.7 \mathrm{~mm}$; thickness $=30.6 \pm 6.8 \mathrm{~mm}$; and wet weight $=72.5 \pm 23.4 \mathrm{~g}$.

An external parasite, the polychaete Neanthes succinea (Frey and Leuckart, 1847), was observed during the macroscopic analyses on the oysters. This parasite drills tubes and tunnels into the inner structure of the shells and allows polydiariosis to become established (Figure 2). Infestation by the polychaete $N$. succinea was found in $41 \%$ of the oysters: the parasite's tubes were observed in $28.4 \%$ of the oysters, marks made by the parasite inside the shell were seen in $31.9 \%$ and mud blisters were seen in $20.8 \%$.

In September and December 2011 and in January and February 2012, the oysters did not show any polychaete tubes in the valves. Formation of mud blisters and presence of polychaetes in the internal valves were found in $100 \%$ of the oysters in December 2011, while in June and November, none were found.

During microscopic analyses, organisms from bacterial, protozoan and metazoan groups were observed. The parasites found were as follows: the protozoan Ancistrocoma sp., the turbellarian Urastoma sp., the metacestode Tylocephalum sp., colonies of Rickettsia-like organisms (RLOs), Nematopsis sp. and an unidentified tapeworm.

The protozoan Nematopsis sp. (Figure 3a) occurred in $98.7 \%$ of the oysters analyzed. This parasite was only not detected in three oyster specimens in June 2011 (one specimen) and September 2011 (two specimens). The parasite prevalence was $85.7 \%$ in the mantle; $79.0 \%$ in digestive tract; $70.7 \%$ in the gills; $50.7 \%$ in the adductor muscle; and $35.9 \%$ in the gonads. The average size of the oocysts was $12.2 \pm 1.2 \mu \mathrm{m} ; \mathrm{n}=25$. The number of oocysts
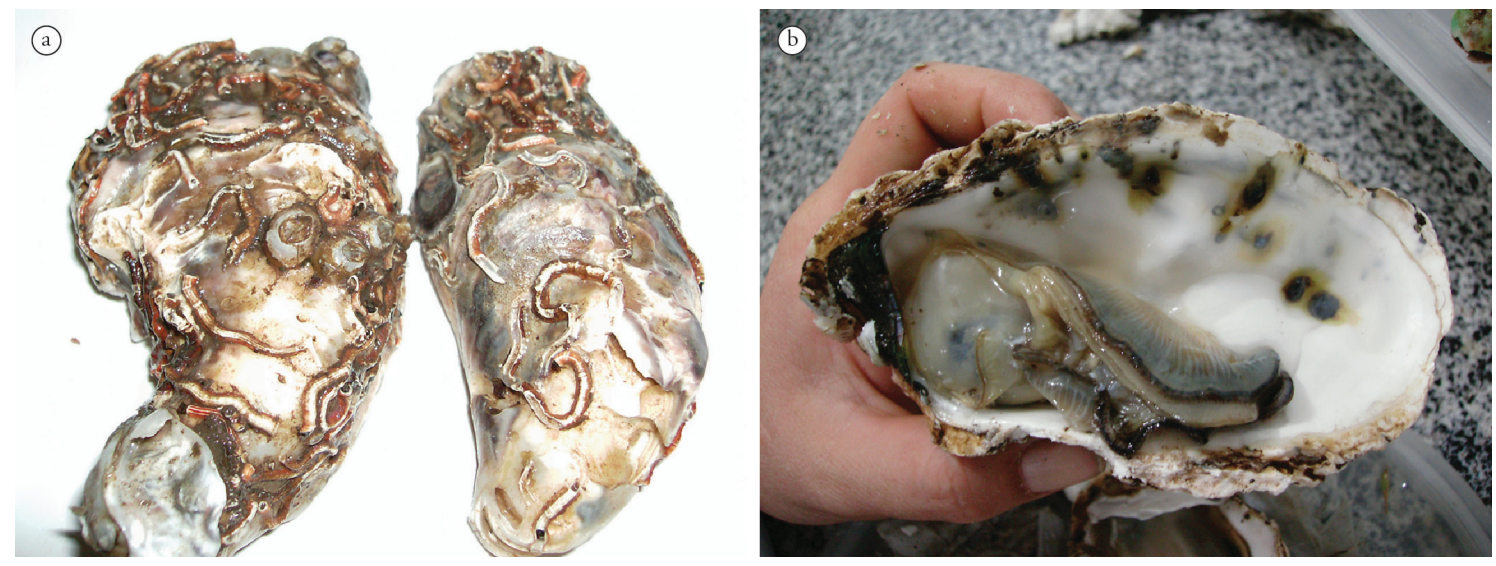

Figure 2. Polydiariosis in Crassostrea rhizophorae. a) External view of the shell, showing the tubes of the polychaete Neanthes succinea; and b) internal view of shell with mud blisters. 

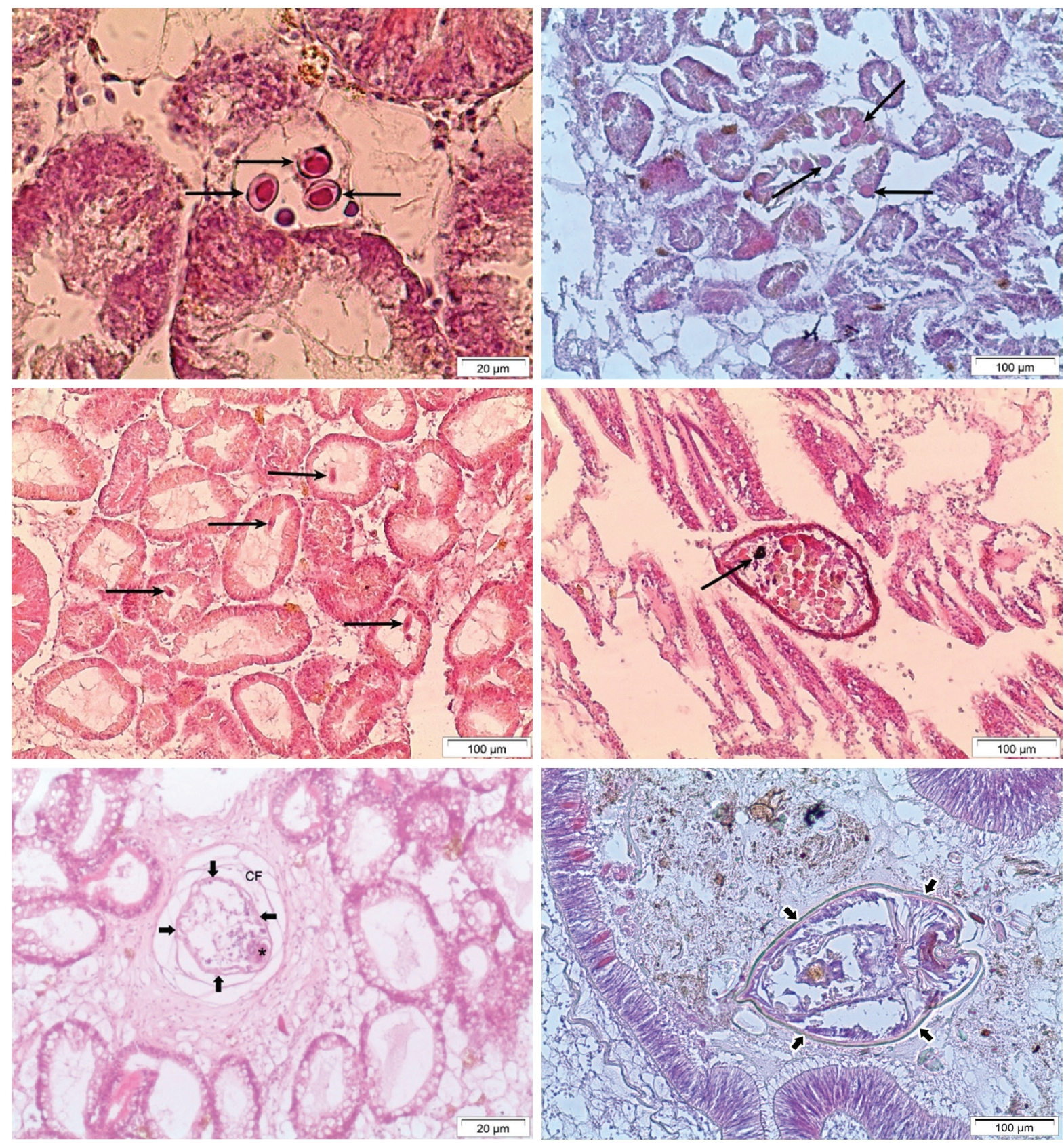

Figure 3. Parasites in the oyster Crassostrea rhizophorae. a-c: digestive gland, showing: a: Nematopsis sp. between the acini, b: colonies of Rickettsia-like organisms inside the acinus and c: Ancistrocoma sp. inside the acini; d: Urastoma sp. in the gill filaments; e: Tylocephalum sp. with a fibrous capsule (marked as CF) and myzorhynchus of the metacestode $\left(^{*}\right)$ between the acini of the digestive gland; f: unidentified flatworm in the lumen of the digestive tract.

per phagocyte ranged from one to eleven, but in most cases, the numbers were from one to three. In only one specimen there was disorganization in the labial pulp tissue, i.e. showing damage caused by the parasite.

Colonies of Rickettsia-like organisms (RLOs) were observed with a prevalence of $8.3 \%$ (20 oysters) in the digestive gland (Figure $3 \mathrm{~b}$ ). The diameters of these colonies ranged from 9.2 to $16.44 \mu \mathrm{m}(13.6 \pm 1.9 \mu \mathrm{m} ; \mathrm{n}=26)$. Up to 34 colonies were observed per histological section and 13 colonies per acinus of the digestive gland. In most cases, there were four colonies/acinus.

The ciliate Ancistrocoma sp. was observed in the lumen of the digestive tract (Figure 3c), with a prevalence of 6.6\% (16 oysters).
The ciliate had an oval shape, with its length ranging from 18.3 to $27.1 \mu \mathrm{m}(22.2 \pm 3.3 \mu \mathrm{m} ; \mathrm{n}=10)$, and a granular and basophilic macronucleus. The infection intensity was low, at an average of six protozoa per histological section, but up to three ciliates were observed in the lumen of the digestive tract.

Urastoma sp. was observed in $6.28 \%$ of the oysters analyzed (Figure 3d). This metazoon was only found in the gill filaments, with only one turbellarian per histological session, with the exception of one histological section, which featured two. No histological changes to oyster tissue were observed.

One specimen of the metacestode Tylocephalum sp. was found encapsulated in an oyster, between the acini of the digestive 
gland (Figure 3e). In this case, a localized hemocytic reaction was observed. The prevalence was $0.42 \%$.

In a sample of $C$. rhizophorae, an unidentified flatworm was found inside the lumen of the digestive tube, but did not appear to be causing any damage (Figure 3f).

\section{Discussion}

Cultivation of bivalve mollusks serves as a marine substrate for fouling organisms, and this is favored by the constant immersion. Fouling organisms can fix themselves both on cultivation structures and on the bivalves themselves, often harming their growth, and this stress leads to a weakening of the animals' defensive capabilities, thus making them more susceptible to disease (MAGALHÁES \& FERREIRA, 2006).

The high infestation rates of Neanthes succinea in this study (41\%) did not cause morphological changes to the tissues of cultivated oysters. Presence of Polydora websteri was recorded in $100 \%$ of the C. rhizophorae and C. gigas oysters in cultivation areas in Brazil's southern regions (SABRY \& MAGALHÂES, 2005; MACIEL et al., 2010). Despite the high level of infestation in the oysters analyzed, no damage was observed in their tissue. These parasites do not compromise the host's health, but formation of mud blisters affects the appearance, taste and market value of these mollusks (SABRY \& MAGALHÁES, 2005). In the present study, in November 2011 and in January and February 2012, polychaete tubes were not observed. However, this was due to the oyster cleaning process that was performed before the specimens were collected. In December 2011, when the temperature and salinity reached the period's highest levels, high rates of polychaete infestation and mud blisters in the oysters were observed, thus suggesting that greater infestation occurs during periods of high temperatures and salinities. The water temperature and salinity, as reported by Lauckner (1983), are primary factors in determining the abundance of Polydora bristle worms.

Presence of Nematopsis sp. has frequently been recorded in C. rhizophorae. Similarly to polychaetes, this parasite has been reported not to cause significant damage to its host's health (NASCIMENTO et al., 1986; BOWER et al., 1994; AZEVEDO \& MATOS, 1999; WINSTEAD et al., 2004; CREMONTE et al., 2005; SABRY et al., 2007; ZEIDAN et al., 2012). However, the gill functions of host animals, which are severely infected by these gregarines, may be compromised (CARBALLAL et al., 2001; ESTEPA, 2006). Regarding this parasite, as was reported by Zeidan et al. (2012), the present study found a range of one to three oocysts per phagocyte in most cases. Pinto \& Boehs (2008) studied Nematopsis sp. in M. guyanensis, in the Ilhéus region of the state of Bahia, and observed that the number of oocysts/phagocyte ranged from one to twenty and that the most common range of occurrence was 1-3 oocysts/phagocyte. However, it is possible that this is a species differing from Nematopsis.

The areas with the highest frequency of Nematopsis sp. infection were the mantle, digestive gland, gills and adductor muscle. These results were consistent with observations made by Brandão et al. (2013) in C. rhizophorae and were also similar to those of Pinto \& Boehs (2008) in M. guyanensis, where the greatest infection occurred in the gills, followed by the mantle, digestive gland and muscle.

The frequency of these gregarines in bivalve mollusks is associated with the presence of large numbers of crustaceans in the mangroves: these are the organisms in which these protozoa complete their life cycle (BOEHS et al., 2009, 2010), and this point was also observed in the present study. During collection, a great quantity of crustaceans of the Porcellanidae and Xantidae families was observed in the oyster cultivation lantern nets.

Nascimento et al. (1986) observed 100\% occurrence of Nematopsis sp. in C. rhizophorae in the Baía de Todos os Santos, in the state of Bahia, and concluded that the parasite was not the determining factor for the observed oyster mortality. In this study, the occurrences of Nematopsis sp. did not cause any apparent histopathological change in the host, and even though the prevalence was high, the infection intensity in the tissue was low.

The Rickettsia-like organisms (RLOs) observed in this study did not cause any microscopic changes to the oyster tissue. Bower et al. (1994) stated that occurrences of RLOs are generally of low intensity and their presence is not associated with disease. However, other studies have indicated more severe effects, such as rupturing of the digestive tubules, which contain larger colonies (CREMONTE et al., 2005). Villalba et al. (1999) found high prevalence of RLOs in mollusks, with an inflammatory reaction and disorganization of gill architecture, which possibly undermines gill function and suggests that these bacteria may be responsible for mortalities in Venerupis rhomboides.

The occurrences of the ciliate Ancistrocoma sp. did not compromise the tissues in C. rhizophorae. This ciliate is associated with the gill surfaces and the bivalve digestive gland and it uses the host cell as a food source (RUSSEL, 1967). In Crassostrea virginica (WINSTEAD et al., 2004), C. gigas (PONTINHA, 2009) and C. rhizophorae (ZEIDAN et al., 2012; BRANDÁO et al., 2013), it is often found in the digestive gland. However, in C. rhizophorae, this parasite was only observed at low prevalence and infection intensity in the digestive tubules, without causing significant damage to the host (BOWER et al., 1994; VILLALBA et al., 1997; WINSTEAD et al., 2004; SILVA \& VILLALBA, 2004; PONTINHA, 2009; ZEIDAN et al., 2012; BRANDÃO et al., 2013). The opportunistic behavior of this ciliate contributes towards its greater frequency of occurrence in bivalves, especially those that show physiological stress caused by other pathogens (RUSSEL, 1967; LAUCKNER, 1983). In the present study, the oysters that were infested by this ciliate were parasitized by Nematopsis sp. and RLOs at lower intensity.

Zeidan et al. (2012) and Brandão et al. (2013) also studied C. rhizophorae on the coast of Bahia and observed Urastoma sp. in the gills and mantle, with a range from one to three histological specimens per section, and no histological change was observed. Brun et al. (1999) confirmed that the greatest attraction was between $U$. cyprinae (Graff, 1882) and the oyster C. virginica, in relation to Mytilus edulis, and also found that the greatest occurrences were in the gills and mantle.

The nature of the parasite/host relationship between Turbellaria and marine bivalves is not yet well defined. These parasites have been more frequently referred to as guests that do not cause any damage to their hosts (LAUCKNER, 1983; BOWER et al., 1994; 
BRUN et al., 1999). However, at high infection levels, they can be considered to be pathogenic and cause macroscopic lesions, highlighted by localized white patches and microscopic changes that are characterized by disorganization in the branchial filaments, hypertrophy of the epithelial cells and hemocytic infiltration, with evidence of reduced filtration capacity (ZEIDAN et al., 2012).

The occurrence area (digestive gland) of the metacestode Tylocephalum sp. confirms previous records, as observed in C. rhizophorae (NASCIMENTO et al., 1986; SABRY \& MAGALHÁES, 2005; SABRY et al., 2007); in studies on other bivalves (A. brasiliana and Iphigenia brasiliana) by Boehs et al. (2010); and in C. gigas (SABRY \& MAGALHÃES, 2005). Ceuta \& Boehs (2012) found Tylocephalum sp. in the mantle, gills, digestive gland and labial pulp of $M$. guyanensis. In all of these studies, a defense reaction was observed in the host, with formation of a fibrous capsule around the metacestode, without any damage to the host, because of the reabsorption process (ZEIDAN et al., 2012). The same responses were observed in other mollusks such as Tapes semidecussata (CHENG \& RIFKIN, 1968), C. virginica (WINSTEAD et al., 2004), C. rhizophorae (SABRY \& MAGALHÂES, 2005) and A. brasiliana and I. brasiliana (BOEHS \& MAGALHĀES, 2004; BOEHS et al., 2010).

\section{Conclusion}

Oysters in the Graciosa River estuary are affected by seven parasites, at low intensities, which suggests that these bivalves are in good condition. Polychaete infestation in the shell affects the oysters' appearance through formation of mud blisters, thereby impairing the product quality. Management techniques need to be optimized in order to remove these organisms from the oysters and cultivation structures.

\section{Acknowledgements}

To the Bahia State Foundation for Research Support (FAPESB), for granting a master's scholarship to the first author.

\section{References}

Abollo E, Ramilo A, Casas SM, Comesaña P, Cao A, Carballal MJ, et al. First detection of the protozoan parasite Bonamia exitiosa (Haplosporidia) infecting flat oyster Ostrea edulis grown in European waters. Aquaculture 2008; 274(2-4): 201-207. http://dx.doi.org/10.1016/j.aquaculture.2007.11.037.

Azevedo C, Matos E. Description of Nematopsis mytella n. sp. (Apicomplexa), parasite of the mussel Mytella guyanensis (Mytelidae) from the Amazon Estuary and description of its oocysts. Eur J Protistol 1999; 35(4): $427-$ 433. http://dx.doi.org/10.1016/S0932-4739(99)80052-2.

Boehs G, Lenz TM, Villalba A. Xenomas in Crassostrea rhizophorae (Ostreidae) from Camamu Bay, Bahia, Brazil. Braz J Biol 2009; 69(2): 457-458. http://dx.doi.org/10.1590/S1519-69842009000200032. PMid:19675953

Boehs G, Magalhães ARM, Sabry RC, Ceuta LO. Parasitos e patologias de bivalves marinhos de importância econômica da costa brasileira. In: Silva
Souza AT, Lizama MLA, Takemoto R. Patologia e sanidade de organismos aquáticos. Maringá: ABRAPOA; 2012. p. 165-194.

Boehs G, Magalhães ARM. Simbiontes associados com Anomalocardia brasiliana (Gmelin) (Mollusca, Bivalvia, Veneridae) na Ilha de Santa Catarina e região continental adjacente, Santa Catarina, Brasil. Rev Braz Zool 2004; 21(4): 865-869. http://dx.doi.org/10.1590/S010181752004000400021 .

Boehs G, Villalba A, Ceuta LO, Luz JR. Parasites of three commercially exploited bivalve mollusc species of the estuarine region of the Cachoeira river (Ilhéus, Bahia, Brazil). J Invertebr Pathol 2010; 103(1): 43-47. http:// dx.doi.org/10.1016/j.jip.2009.10.008. PMid:19850046

Bower SM, McGladdery SE, Price IM. Synopsis of infectious diseases and parasites of commercially exploited shellfish. Annu Rev Fish Dis 1994; 4(1): 1-199. http://dx.doi.org/10.1016/0959-8030(94)90028-0

Brandão RP, Boehs G, Silva PM. Health assessment of the oyster Crassostrea rhizophorae on the southern coast of Bahia, northeastern Brazil. Rev Bras Parasitol Vet 2013; 22(1): 84-91. http://dx.doi.org/10.1590/S198429612013005000007. PMid:23538501

Brun NT, Boghen AD, Allard J. Attraction of Urastoma cyprinae (Turbellaria: Urastomidae) to the eastern oyster Crassostrea virginica. Dis Aquat Organ 1999; 37(2): 139-144. http://dx.doi.org/10.3354/ dao037139. PMid:10092977

Bush AO, Lafferty KD, Lotz JM, Shostak AW. Parasitology meets ecology on its own terms: Margolis et al. revisited. J Parasitol 1997; 83(4): $575-$ 583. http://dx.doi.org/10.2307/3284227. PMid:9267395

Carballal MJ, Iglesias D, Santamarina J, Ferro-Soto B, Villalba A. Parasites and pathologic conditions of the cockle Cerastoderma edule populations of the coast of Galicia (NW Spain). J Invertebr Pathol 2001; 78(2): 87-97. http://dx.doi.org/10.1006/jipa.2001.5049. PMid:11812111

Ceuta LO, Boehs G. Parasites of the mangrove mussel Mytella guyanensis (Bivalvia: Mytilidae) in Camamu Bay, Bahia, Brazil. Braz J Biol 2012; 72(3): 421-427. http://dx.doi.org/10.1590/S1519-69842012000300002. PMid:22990810

Cheng TC, Rifkin E. The occurrence and resorption of Tylocephalum metacestodes in the clam Tapes semidecussata. J Invertebr Pathol 1968; 10(1): 65-69. http://dx.doi.org/10.1016/0022-2011(68)90264-4. PMid:5649244

Costa RL. Prevalência de enfermidades e histopatologia de Perna perna (Mollusca) em Florianópolis/SC, Brasil [Dissertação]. Florianópolis: Universidade Federal de Santa Catarina; 2007.

Cremonte F, Balseiro P, Figueras A. Occurrence of Perkinsus olseni (Protozoa: Apicomplexa) and other parasites in the venerid commercial clam Pitar rostrata from Uruguay, southwestern Atlantic coast. Dis Aquat Organ 2005; 64(1): 85-90. http://dx.doi.org/10.3354/dao064085. PMid:15900692

Estepa DI. Estudio patológico de las poblaciones de berberecho Cerastoderma edule (L.) de Galicia. Santiago de Compostela, Galicia [Tese]. Espanha: Universidade de Santiago de Compostela; 2006.

Food and Agriculture Organization of the United Nations - FAO. Departamento de Pesca y Acuicultura. Ostrea edulis (Linnaeus, 1758) [Ostreidae] [online]. 2013 [cited 2013 Out 8]. Available from: http:// www.fao.org/fishery/culturedspecies/Ostrea_edulis/es.

Galtsoff PS. The American oyster, Crassostrea virginica (Gmelin). Fishery Bull Nat Mar Fish Serv 1964; 64(1): 1-480.

Howard DW, Lewis EJ, Keller BJ, Smith CS. Histological techniques for marine bivalve mollusks and crustaceans. 2004. 218 p. National Oceanic and 
Atmospheric Administration, United States Department of Commerce. vol. 5. NOAA Technical Memorandum NCCOS. Available from: http:// www.noaa.gov/organizations.html.

Lauckner G. Diseases of Mollusca: Bivalvia. In: Kinne O. Diseases of marine animals. Hamburg: Biologische Anstalt Helgoland; 1983. p. 478-961. vol. 2.

Lee CY, Panicker G, Bej AK. Detection of pathogenic bacteria in shellfish using multiplex PCR followed by CovaLink NH microwell plate sandwich hybridization. J Microbiol Methods 2003; 53(2): 199-209. http://dx.doi. org/10.1016/S0167-7012(03)00032-0. PMid:12654491

Maciel MLT, Ibbotson DP, Magalhães ARM. Polidiariose em Crassostrea gigas cultivadas na Praia da Ponta do Sambaqui, Florianópolis, Santa Catarina - Brasil. Braz J Vet Res Anim Sci 2010; 47(5): 337-345.

Magalhães ARM, Ferreira JF. Patologias e manejo em malacocultura. In: Souza-Silva AT. Sanidade de organismos aquáticos no Brasil. Parte II. Maringá: ABRAPOA; 2006. p. 79-94.

Narchi W. Encontro de Bucephalopsis haimeana (Lacaze-Duthiers) no Brasil. Cienc Cult 1966; 18: 22-24.

Nascimento IA, Smith DH, Kern IIF 2nd, Pereira SA. Pathological findings in Crassostrea rhizophorae from Todos os Santos Bay, Bahia, Brazil. J Invertebr Pathol 1986; 47(3): 340-349. http://dx.doi.org/10.1016/00222011(86)90105-9.

Pinto TR, Boehs G. Nematopsis sp. (Apicomplexa: Eugregarinida) em Mytella guyanensis (Lamarck, 1819) (Bivalvia: Mytilidae) da região estuarina do Rio Cachoeira, Ilhéus, Bahia, Brasil. Braz J Vet Res Anim Sci 2008; 45(2): 95-100.

Pontinha VA. Diagnóstico da saúde da ostra Crassostrea gigas (Thunberg, 1793) cultivada em Florianópolis/SC [Dissertação]. Florianópolis: Universidade Federal de Santa Catarina; 2009.

Russel FS. Advances in marine biology. London: Academic Press; 1967. vol. 5 .
Sabry RC, Gesteira TCV, Boehs G. First record of parasitism in the mangrove oyster Crassostrea rhizophorae (Bivalvia: Ostreidae) at Jaguaribe River estuary - Ceará, Brazil. Braz J Biol 2007; 67(4): 755-758. http:// dx.doi.org/10.1590/S1519-69842007000400024. PMid:18278331

Sabry RC, Magalhães AR. Parasitas em ostras de cultivo (Crassostrea rhizophorae e Crassostrea gigas) da Ponta do Sambaqui, Florianópolis, SC. Arq Bras Med Vet Zootec 2005; 57(S2): 194-203.

Superintendência de Estudos Econômicos e Sociais da Bahia - SEI. [online] 2013 [cited 2013 jul 15]. Available from: http://www.sei.ba.gov.br/side/ frame_tabela.wsp?tmp.volta $=s g 6 \&$ tmp.tabela $=\mathrm{t} 78$.

Silva PM, Magalhães ARM, Barracco MA. Effects of Bucephalus sp. (Trematoda: Bucephalidae) on Perna perna mussels from a culture station in Ratones Grande Island, Brazil. J Invertebr Pathol 2002; 79(3): 154-162. http://dx.doi.org/10.1016/S0022-2011(02)00026-5. PMid:12133704

Silva PM, Villalba A. Comparison of light microscopic techniques for the diagnosis of the infection of the European flat oyster Ostrea edulis by the protozoan Bonamia ostreae. J Invertebr Pathol 2004; 85(2): 97-104. http://dx.doi.org/10.1016/j.jip.2003.12.010. PMid:15050839

Villalba A, Mourelle SG, Carballal MJ, López C. Symbionts and diseases of farmed mussels Mytilus galloprovincialis throughout the culture process in the Rías of Galicia (NW Spain). Dis Aquat Organ 1997; 31(2): $127-$ 139. http://dx.doi.org/10.3354/dao031127.

Villalba A, Carballal MJ, López C, Cabada A, Corral L, Azevedo C. Branchial Rickettsia-like infection associated with clam Venerupis rhomboides mortality. Dis Aquat Organ 1999; 36(1): 53-60. http://dx.doi. org/10.3354/dao036053.

Winstead JT, Volety AK, Tolley SG. Parasitic and symbiotic fauna in oysters (Crassostrea virginica) collected from the Caloosahatchee River and estuary in Florida. J Shellfish Res 2004; 23(3): 831-840.

Zeidan GC, Luz MS, Boehs G. Parasites of economically important bivalves from the southern coast of Bahia State, Brazil. Rev Bras Parasitol Vet 2012; 21(4): 391-398. http://dx.doi.org/10.1590/S1984-29612012000400009. PMid:23295820 